\title{
MUTU KULIT CHAMOIS DARI KULIT DOMBA PERANAKAN MERINO
}

\author{
Oleh : Bambang Oetojo, Muchtar Lutfie, Widari, Hasan Basalamah
}

\begin{abstract}
The purpose of this research is to compare the quality of chamois leather output from merino descendent to that one from local sheep skin. In the actualization it was used four pieces of merino descendent sheep skin and four pieces of local sheep skin. The skins was processed into chamois leather. Chamois leathers output from this research, either from merino descendent sheep skin or local sheep skin were visually investigated. Statistical analysis points out that there is unsignify difference $(P \leq 0,05)$ the influence of the species either it is merino descendent sheep skin or local one to the quality of chamois leather. Practical meaning of this research is that merino descendent sheep skin may be tanned into chamois leather having some quality to that one from local sheep skin.
\end{abstract}

\section{PENDAHULUAN}

Tujuan utama menternakkan domba merino adalah untuk diambil woolnya, karena domba merino dapat menghasilkan wool yang lebat serta panjang. Kulit domba merino keadaannya lemah, rajahnya ber-bentuk lipatan-lipatan seperti tulang rusuk dan merupakan kulit yang kualitasnya paling rendah dari semua jenis domba. Sehingga apabila kulit domba merino disamak, kulit jadi yang dihasilkan mutunya tidak baik.

Sekarang telah dikawinkan secara silang antara domba merino dengan domba lokal. Domba peranakan hasil silang tersebut telah banyak dipelihara orang. Dengan dipeliharanya domba peranakan merino untuk diambil dagingnya, maka perlu pula dimanfaatkan kulitnya dalam industri kulit, untuk disamak menjadi 
ermacam-macam kulit jadi.

Mutu kulit jadi yang dihasilkan dengan menggunakan kulit domba lokal, liperkirakan akan lebih baik dari pada menggunakan kulit domba merino, meskioun demikian perlu diadakan penelitian. Dalam hal ini mengenai mutu kulit chamois dari kulit domba peranakan merino. Sebagai pembanding digunakan kulit lomba lokal.

- Proses penyamakan kulit menggunakan metoda kombinasi antara formalin dan oahan penyamak minyak dengan angka jod 80-120. Formalin berfungsi agar kulit mentah mudah diampelas, baik pada bagian daging maupun bagian rajah.

\section{MATERI DAN METODA}

\section{Materi}

Penelitian ini menggunakan bahan baku kulit domba peranakan merino sebanyak empat lembar. Kulit tersebut diawet dengan garam. Sedang sebagai pembanding digunakan bahan baku kulit domba lokal yang diawet dengan garam pula.

Bahan penyamak yang digunakan adalah formalin dan bahan penyamak minyak dengan angka jod antara 80-120. Bahan pembantu yang digunakan adalah $\mathrm{Na}_{2} \mathrm{~S}, \mathrm{Ca}(\mathrm{OH})_{2},\left(\mathrm{NH}_{4}\right)_{2} \mathrm{SO}_{4}, \mathrm{H}_{2} \mathrm{SO}_{4}, \mathrm{HCOOH}, \mathrm{HCOH}, \mathrm{Na}_{2} \mathrm{CO}_{3}$, dan bahan pengurang lemak.

Alat-alat yang digunakan adalah bak perendaman, bak pengapuran, pisau buang bulu, pisau buang daging, drum penyamakan, timbangan, mesin sekrap dan mesin ampelas.

\section{Metoda}

Bahan baku, baik kulit domba peranakan merino maupun kulit domba lokal disamak menjadi kulit chamois dengan metoda yang ada di Balai Besar Penelitian dan Pengembangan Industri Barang Kulit, Karet dan Plastik. Dalam proses penyamakan digunakan empat lembar kulit domba peranakan merino dan empat lembar kulit domba lokal. Adapun fungsi kulit domba lokal adalah sebagai pembanding. Setiap perlakuan menggunakan dua lembar kulit domba peranakan merino dan dua lembar kulit domba lokal dengan satu kali ulangan.

Adapun langkah-langkah yang dikerjakan dalam penyamakan kulit chamois adalah sebagai berikut :

\section{Pencucian (Washing)}

Proses pencucian dimaksudkan untuk menghilangkan garam pengawet, karena kulit yang digunakan dalam penelitian diawet dengan garam. Kulit dicuci dalam drum. Air masuk melalui as drum yang berlubang dan keluar melalui tutup drum yang berlubang-lubang pula. Pada waktu pencucian drum diputar selama 60 menit atau sampai garam pengawet benar-benar bersih.

\section{Pengapuran (Liming)}

Untuk menghilangkan bulu, epidermis, zat-zat bukan collagen serta untuk membengkakkan kulit, maka dilakukan proses pengapuran. Proses pengapuran dilaksanakan dengan cara merendam kulit di dalam suatu larutan yang terdiri atas air sebesar $400 \%, \mathrm{Na}_{2} \mathrm{~S}$ sebesar $5 \%$ dan $\mathrm{Ca}(\mathrm{OH})_{2}$ sebesar $8 \%$. Untuk setiap 60 menit diaduk-aduk selama 15 menit dan selanjutnya direndam selama 24 jam.

\section{Pembuangan Kapur (Deliming)}

Proses pembuangan kapur dimaksudkan untuk menghilangkan kapur dan alkali lainnya karena kapur dan alkali lainnya tersebut akan memberikan pengaruh yang tidak baik pada proses penyamakan. Proses pembuangan kapur dikerjakan di dalam drum. Kulit diputar di dalam drum dengan suatu larutan yang terdiri atas air sebesar $200 \%$ dan $\left(\mathrm{NH}_{4}\right)_{2} \mathrm{SO}_{4}$ sebesar $0,5 \% . \mathrm{H}_{2} \mathrm{SO}_{4}$ sebesar $1,0 \%$ yang telah diencerkan lebih dulu dengan air, ditambahkan ke dalam drum yang telah diputar. Apabila penampang kulit telah berwarna putih terhadap indikator phenolphtalein, maka dapat dikatakan bahwa proses pembuangan kapur telah selesai. Waktu yang diperlukan dalam proses ini kira-kira 60 menit.

\section{Pengikisan Protein (Bating)}

Maksud proses pengikisan protein adalah untuk membuat kulit agar tidak lenting. Proses pengikisan protein ini merupakan proses enzimatik dan merupakan langkah selanjutnya dalam pemurnian kulit sebelum proses penyamakan dilaksanakan. Pada umumnya pengikisan protein dikerjakan setelah proses pembuangan kapur, karena setelah proses pembuangan kapur $\mathrm{pH}$ kulit berada antara 8,0-9,0. Adapun pelaksanaannya adalah dengan menambahkan bahan pengikis protein ke dalam larutan pada proses pembuangan. Pemakaian bahan pengkis protein sebesar $0,5 \%$ dan waktu yang diperlukan untuk proses pengikisan protein kira-kira 60 menit, atau apabila kulit ditekan dengan ibu jari bekasnya tidak lekas kembali.

\section{Penyamakan Pendahuluan (Pretanning)}

Proses ini dimaksudkan agar kulit tidak licin lagi dan mudah diketam, baik pada bagian rajah maupun pada bagian daging. Proses penyamakan pendahuluan dilaksanakan dengan memutar kulit di dalam drum dengan suatu larutan yang terdiri atas air sebesar $100 \% \mathrm{Na}_{2} \mathrm{CO} 3$ sebesar $3 \%$ dan $\mathrm{HCOH}$ sebesar $5 \%$. Waktu yang diperlukan dalam proses penyamakan pendahuluan lebih kurang 60 menit. Selanjutnya bagian rajah dan bagian daging diketam sampai betul-betul bersih.

\section{Penyamakan (Tanning)}

Penyamakan adalah suatu proses yang merubah kulit mentah menjadi kulit jadi, sehingga zat-zat kulit yang mudah rusak menjadi tahan terhadap mikroorganisme. Adapaun caranya ialah, kulit bersama minyak ikan mentah sebagai bahan penyamak dimasukkan ke dalam drum. Minyak ikan mentah yang dibutuhkan 
sebesar $30 \%$. Selanjutnya drum diputar selama 24 jam agar bahan penyamak benar-benar masuk ke dalam kulit. Selanjutnya kulit dikeringkan dengan cara diangin-anginkan sampai betul-betuk masak, yaitu kulit menjadi tembus cahaya dan apabila ditarik bekasnya menjadi kuning.

\section{Pencucian (Washing)}

Tidak semua bahan penyamak minyak bereaksi seluruhnya dengan kulit. Oleh karena itu proses pencucian ini dimaksudkan untuk menghilangkan kelebihan bahan penyamak minyak dari kulit. Dalam pelaksanannya dilakukan dengan cara memutar kulit di dalam drum selama 60 menit dengan suatu larutan yang terdiri atas 200 gram $\mathrm{Na}_{2} \mathrm{CO}_{2}$ dalam satu liter air hangat $50^{\circ} \mathrm{C}$. Besarnya penggunaan air hangat secukupnya agar dapat merendam kulit. Pencucian dikerjakan dua sampai tiga kali sehingga kelebihan bahan penyamak betul-betul bersih.

\section{Pengeringan (Drying)}

Setelah pencucian selesai, maka kulit harus dikeringkan dengan cara dianginanginkan. Agar proses pengeringan dapat berlangsung cepat, kulit perlu diperah lebih dulu untuk menghilangkan sejumlah air.

\section{Pengampelasan (Buffing)}

Setelah benar-benar kering, kemudian kulit diampelas dengan mesin ampelas, baik pada bagian daging maupun pada bagian rajah. Tujuannya adalah agar permukaan kulit menjadi halus seperti beledu.

\section{Pengujian}

Kulit chamois hasil penelitian diuji secara organoleptis mengenai mutunya dengan nilai terendah satu dan nilai tertinggi sepuluh.

\section{Analisa data}

Data hasil uji kualitas kulit chamois dianalisa secara statistik dengan analisa varians.

\section{HASIL DAN PEMBAHASAN}

Nilai rata-rata hasil uji kualitas kulit chamois secara organoleptis dapat dilihat pada Tabel 1. Setelah data pada Tabel 1. dianalisa secara statistik dengan analisa varians pada Tabel 2 ., ternyata tidak terdapat perbedaan yang nyata $(\mathrm{P} \leq 0,05)$ pada pengaruh jenis kulit domba terhadap kualitas kulit chamois yang dihasilkan. Dengan demikian dapat dikatakan bahwa kulit domba peranakan merino dapat disamak menjadi kulit chamois dengan kualitas yang sama dengan jika menggunakan bahan baku kulit domba lokal.
TABEL 1.

NILAI RATA-RATA HASIL UJI KUALITAS KULIT CHAMOIS SECARA ORGANOLEPTIS

\begin{tabular}{lllll}
\hline Jenis kulit & \multicolumn{5}{c}{ Nilai kualitas } \\
\hline Domba peranakan & 6,80 & 6,80 & 6,20 & 6,30 \\
Domba lokal & 6,30 & 6,60 & 6,60 & 6,70 \\
\hline
\end{tabular}

TABEL 2. ANALISA VARIANS NILAI KUALITAS KULIT CHAMOIS

\begin{tabular}{lcccc}
\hline S O V & df & SS & MS & Fh \\
\hline Perlakuan & 1 & 0,003 & 0,003 & \\
Error & 6 & 0,396 & 0,066 & 0,045 NS \\
\hline
\end{tabular}

\section{KESIMPULAN}

Dari hasil penelitian dapat diambil kesimpulan bahwa tidak terdapat beda nyata $(P \leq 0,05)$ pengaruh jenis kulit domba terhadap mutu kulit chomais yang dihasilkan. Dengan demikian dapat dikatakan bahwa mutu kulit chamois dari kulit domba peranakan merino sama dengan mutu kulit domba chamois dari kulit domba lokal.

\section{UCAPAN TERIMA KASIH}

Dengan selesainya penelitian dan tersusunnya tulisan ini, kami mengucapkan banyak terima kasih kepada Departemen Perindustrian RI, Bapak Kepala BBKKP, Ibu Kepala Penelitian Barang Kulit dan semua staf yang telah memberikan pengarahan, bimbingan, biaya serta bantuan lainnya sehingga penelitian dapat dilaksanakan dan tersusunnya laporan ini. 


\section{DAFTAR PUSTAKA}

1. Balai Penelitian Kulit: Proses Penyamakan Kulit, Yogyakarta, (1972).

2. Busono : Struktur Kulit atau Susunan Jaringan Kulit, Yogyakarta, (1962).

3. Departemen Perindustrian RI : Mutu dan Cara Uji Kulit Chamois Dombal Kambing, SII. 0063-74, Jakarta.

4. Gustavson, K.H. : The Chemistry of Tanning Processes, Academis Press Inc. Publishers, New York, (1974).

5. Mann, I. : Rural Tanning Techniques, Food and Agricultural Organization of the Limited Nation, Rome (1960).

6. Sarkar, K.T. : Theory and Practice of Leather Manufacture, A.M. Sharif., 555, Poonamallee High Road, Madras (1974).

7. Sharphouse, J.H. : Leather Technician's Hand Book, Leather Product Association, London (1971).

8. Steel, R.G. and J.H. Torrio : Principle and Procedure of Statistic, Mc. Graw Hill Book Co., Inc., New York (1960).

9. Thorstensen, T.C. : Practical Leather Technology, Robert E. Krieger Publishing Co., Huntington, New York (1976). 